\title{
Effect of Different Level of Phosphorus and Sulphur on Growth and Yield Attributes of Sesame
}

\author{
N. K. Kalegore, G. D. Kirde*, S. A. Bhusari, S. V. Kasle and R. I. Shelke
}

Agronomy Section, College of Agriculture, VNMKV, Latur, Maharashtra (413 512), India

\section{Corresponding Author}

G. D. Kirde

e-mail: gajukirde111@gmail.com

\author{
Article History \\ Article ID: IJEP0264 \\ Received in $16^{\text {th }}$ July, 2018 \\ Received in revised form $13^{\text {th }}$ September, 2018 \\ Accepted in final form $28^{\text {th }}$ September, 2018
}

\begin{abstract}
A field experiment was conducted to study the effect of different level of phosphorus and sulphur on yield attributes and yield of sesame during kharif 2011-12 at Department of Agronomy, College of Agriculture, Latur. The soil of the experimental plot was clay texture, low in available nitrogen (186.8 $\left.\mathrm{kg} \mathrm{ha}^{-1}\right)$, medium in available phosphorous (15.9 kg ha $\left.{ }^{-1}\right)$, high in available potassium (343.2 kg ha-1) and slightly alkaline $(\mathrm{pH} 8.02)$ in reaction. The experiment field was uniform and well levelled. Gross plot size was $5.4 \times 4.2 \mathrm{~m}^{2}$ and net plot size was $4.5 \times 3.6 \mathrm{~m}^{2}$ respectively. The experiment was laid out in Factorial Randomized Block Design with three replications. The spacing $675 \mathrm{~cm}^{2}$ and recommended dose of fertilizers $\left(50: 25: 00 \mathrm{NKK} \mathrm{ha}^{-1}\right)$ were used. The treatments consists of three levels each of phosphorus and sulphur. The phosphorus applied as $20 \mathrm{~kg} \mathrm{P}_{2} \mathrm{O}_{5}$ ha $^{-1}, 25 \mathrm{~kg} \mathrm{P}_{2} \mathrm{O}_{5} \mathrm{ha}^{-1}, 30 \mathrm{~kg} \mathrm{P}_{2} \mathrm{O}_{5}$ ha $^{-1}$ and $20 \mathrm{~kg} \mathrm{Sha}^{-1}, 25 \mathrm{~kg} \mathrm{Sha}^{-1}, 30 \mathrm{~kg} \mathrm{Sha}^{-1}$. The application of $30 \mathrm{~kg} \mathrm{P}_{2} \mathrm{O}_{5}$ was recorded significantly higher growth and yield attributing character over the rest of the phosphorus levels. Among three sulphurtreatment $30 \mathrm{~kg}$ sulphur ha-1 was recorded significantly higher growth and yield attributing characters over the application of 20 and $25 \mathrm{~kg}$ sulphur ha-1
\end{abstract}

Keywords: Sesame, phosphorus, sulphur, dry matter, yield

\section{Introduction}

Sesame is an ancient oilseed crop grown throughout India having tremendous potential for export. It offers several advantages by virtue of its faster growth and short duration. However, it has not contributed enormously to the total oilseed production mainly because of average low yield level (323 $\mathrm{kg} \mathrm{ha}^{-1}$ ). Therefore, there is an urgent need to augment its productivity through the incorporation of wide adaptability and high yield potential.India, China, Burma, Sudan, Pakistan, and Mexico are the main sesame producing countries of the world. In India, sesame is important edible oilseed crop, stands next to groundnut. In India it is mainly grown in Gujrat, Uttar Pradesh, Madhya Pradesh, Karnataka, Orissa, Bihar and Tamil Nadu. In Maharashtra, it was grown on 56 thousand hectares with production of 15 thousand tones and productivity of $268 \mathrm{~kg} \mathrm{ha}^{-1}$. Maximum quantity of seeds (78\%) used for oil extraction, edible purpose (20\%) an seed purpose (2\%). Most of the oil of sesame used for edible purposes (73\%) and industrial purposes (4.2\%) in the manufacturing of paint, pharmaceuticals, insecticide and also used as perfume oil. Sesame seed consumed as fried and mixed with sugar Jaggery and oil cake used as cattle feed of millions of animals. Oil cake can be used as manures which contain $6-6.2 \% \mathrm{~N}, 2-2.2 \% \mathrm{P}_{2} \mathrm{O}_{5}$ and $1-1.2 \% \mathrm{~K}_{2} \mathrm{O}$.
India ranks first both in the area and production of sesame. The major sesame producing countries are India, China, Myanmar, Sudan, Pakistan, Mexico, Ethiopia, Srilanka, Burma, Africa, etc. Sesame is an important oilseed crop next to the groundnut. In India major sesame cultivating states are Gujarat, Rajasthan, Madhya Pradesh, Karnataka, Maharashtra, Utter Pradesh, Tamil Nadu, Andhra Pradesh, Kerala and Punjab. In Maharashtra important district growing this crop are Jalgaon, Nashik, Dhule, Pune, Solapur and Latur. Sesame is cultivated on an area about 19.50 lakh ha with production of 8.5 lakh metric tonnes and productivity $436 \mathrm{~kg}$ ha-1. (Anonymous, 2016).

\section{Materials and Methods}

The field experiment carried out at Experimental Farm of Agronomy Section, College of Agriculture, Latur, Maharashtra, India during kharif season of 2011 on sesame (Phule Till No.1). The soil of the experimental plot was clay texture, having good drainage capacity, low in available nitrogen $(186.8 \mathrm{~kg}$ $\left.\mathrm{ha}^{-1}\right)$, medium in available phosphorous (15.9 $\left.\mathrm{kg} \mathrm{ha}^{-1}\right)$, high in available potassium ( $343.2 \mathrm{~kg} \mathrm{ha}^{-1}$ ) and slightly alkaline $(\mathrm{pH}$ 8.02 ) in reaction. The climate of Marathwada region on annual basis can be classified as semi-arid type. The experiment field was uniform and well levelled. Gross plot size was 
$5.4 \times 4.2 \mathrm{~m}^{2}$ and net plot size was $4.5 \times 3.6 \mathrm{~m}^{2}$ respectively. The experiment was laid out in Factorial randomized block design with three replications along with two factors i.e. sulphur and phosphorus. Sowing was done on $5^{\text {th }}$ July, 2011 by dibbling method with spacing $675 \mathrm{~cm}^{2}$ and recommended dose of fertilizers were used (50:25:00 NKK ha-1). The treatments were $\mathrm{P}_{1}: 20 \mathrm{~kg} \mathrm{P}_{2} \mathrm{O}_{5}$ ha $^{-1}, \mathrm{P}_{2}: 25 \mathrm{~kg} \mathrm{P}_{2} \mathrm{O}_{5}$ ha $^{-1}, \mathrm{P}_{3}: 30 \mathrm{~kg} \mathrm{P}_{2} \mathrm{O}_{5}$ ha $^{-1}$ and $\mathrm{S}_{1}$ : $20 \mathrm{~kg} \mathrm{Sha}^{-1} \mathrm{~S}_{1}: 25 \mathrm{~kg} \mathrm{Sha}^{-1} \mathrm{~S}_{1}: 30 \mathrm{~kg} \mathrm{~S} \mathrm{ha}^{-1}$.

\section{Results and Discussion}

\subsection{Effect of phosphorus on growth attributing characters of sesame}

Data pertaining to growth attributes is presented in Table 1 revealed that the maximum plant height $(104.2 \mathrm{~cm})$, number of functional leaves (89), leaf area (18.8), no. of capsules plant $^{-1}$ (58.1), and dry matter accumulation plant ${ }^{-1}$ (19.6 g) was recorded due to the application of $30 \mathrm{~kg}$ phosphorous $\mathrm{ha}^{-1}$ and which was significantly superior over the 20 and 25 kg phosphorous ha-1. The higher no. of branches plant ${ }^{-1}$ (4.2) were recorded due to the application of $30 \mathrm{~kg}$ phosphorus ha-1 and significantly superior over the $20 \mathrm{~kg}$ phosphorus ha-1 but satisfactory at par with $25 \mathrm{~kg}$ phosphorous ha-1.

\subsection{Effect of sulphur on growth attributing characters}

The data presented in Table 1 revealed that the maximum plant height $(102.5 \mathrm{~cm})$, no. of functional leaves (79) and leaf area $\left(18.3 \mathrm{dm}^{2}\right)$ were recorded due to the application of 30 $\mathrm{kg}$ sulphur ha-1. Which was at par with the application of 25 kg sulphur ha ${ }^{-1}$ and significantly superior over the application

\begin{tabular}{|c|c|c|c|c|c|c|}
\hline Treatments & $\begin{array}{l}\text { Mean plant } \\
\text { height }(\mathrm{cm})\end{array}$ & $\begin{array}{l}\text { No. of functional } \\
\text { leaves plant }\end{array}$ & $\begin{array}{c}\text { Leaf area } \\
\text { plant }^{-1}\end{array}$ & $\begin{array}{l}\text { No. of branch- } \\
\text { es plant }{ }^{-1}\end{array}$ & $\begin{array}{l}\text { No. of capsules } \\
\text { plant }^{-1}\end{array}$ & $\begin{array}{l}\text { Total dry mat- } \\
\text { ter plant }{ }^{-1}(\mathrm{~g})\end{array}$ \\
\hline \multicolumn{7}{|c|}{ Phosphorus levels } \\
\hline $\mathrm{P}_{1}: 20 \mathrm{~kg} \mathrm{P} \mathrm{ha}^{-1}$ & 92.2 & 60 & 16.2 & 3.7 & 45.4 & 15.6 \\
\hline $\mathrm{P}_{2}: 25 \mathrm{~kg} \mathrm{P} \mathrm{ha}^{-1}$ & 95.1 & 73 & 17.6 & 3.8 & 48.4 & 17.2 \\
\hline $\mathrm{P}_{3}: 30 \mathrm{~kg} \mathrm{P} \mathrm{ha-1}$ & 104.2 & 80 & 18.8 & 4.2 & 58.1 & 19.6 \\
\hline SEm \pm & 2.97 & 2.2 & 0.55 & 0.14 & 1.60 & 0.53 \\
\hline $\mathrm{CD}(p=0.05)$ & 8.9 & 6.8 & 1.66 & 0.43 & 4.80 & 1.58 \\
\hline \multicolumn{7}{|l|}{ Sulphur levels } \\
\hline $\mathrm{S}_{1}: 20 \mathrm{~kg} \mathrm{~S} \mathrm{ha}^{-1}$ & 90.8 & 70 & 16.5 & 3.6 & 47.7 & 16.0 \\
\hline $\mathrm{S}_{2}: 25 \mathrm{~kg} \mathrm{~S} \mathrm{ha}^{-1}$ & 98.0 & 73 & 17.9 & 3.8 & 49.9 & 17.4 \\
\hline $\mathrm{S}_{3}: 30 \mathrm{~kg} \mathrm{~S} \mathrm{ha}^{-1}$ & 102.5 & 79 & 18.3 & 4.3 & 54.9 & 19.1 \\
\hline SEm \pm & 2.97 & 2.2 & 0.55 & 0.14 & 1.60 & 0.53 \\
\hline $\mathrm{CD}(p=0.05)$ & 8.9 & 6.8 & 1.66 & 0.43 & 4.80 & 1.58 \\
\hline \multicolumn{7}{|l|}{ Interaction $\mathrm{P} \times \mathrm{S}$} \\
\hline SEm \pm & 5.14 & 3.9 & 0.96 & 0.24 & 2.79 & 0.91 \\
\hline $\mathrm{CD}(p=0.05)$ & NS & NS & NS & NS & NS & NS \\
\hline
\end{tabular}

of $20 \mathrm{~kg}$ sulphur ha-1. The higher no. of branches (4.3), no. of capsules (54.9) and dry matter production plant ${ }^{-1}$ (19.9 g), were recorded due to the application of $30 \mathrm{~kg}$ sulphur ha-1and which was significantly superior over the application of 20 and $25 \mathrm{~kg}$ sulphur ha-1.

\subsection{Effect of phosphorus on yield attributing characters}

Data presented in Table 2 revealed that the higher no. of seeds

Table 2: Yield attributes and seed yield as influenced by different treatments

\begin{tabular}{|c|c|c|c|c|c|c|c|c|c|c|}
\hline Treatments & NSP & NSC & WCP & TW & SYP & WCP* & SY & SY* & BY & $\mathrm{HI}$ \\
\hline \multicolumn{11}{|c|}{ Phosphorus levels } \\
\hline$P_{1}: 20$ kg P ha-1 & 1551 & 35.6 & 10.7 & 2.70 & 4.2 & 10.7 & 543 & 1484 & 2028 & 26.7 \\
\hline$P_{2}: 25 \mathrm{~kg} \mathrm{P} \mathrm{ha}^{-1}$ & 1795 & 36.4 & 11.6 & 2.71 & 4.9 & 11.6 & 624 & 1587 & 2211 & 28.2 \\
\hline$P_{3}: 30$ kg P ha ${ }^{-1}$ & 2099 & 43.2 & 13.6 & 2.71 & 5.7 & 13.6 & 728 & 1785 & 2514 & 28.9 \\
\hline SEm \pm & 54 & 1.20 & 0.44 & 0.004 & 0.14 & 0.44 & 19 & 56 & 75 & \\
\hline $\operatorname{CD}(p=0.05)$ & 162 & 3.60 & 1.31 & NS & 0.44 & 1.31 & 58 & 169 & 225 & \\
\hline
\end{tabular}




\begin{tabular}{|c|c|c|c|c|c|c|c|c|c|c|}
\hline Treatments & NSP & NSC & WCP & TW & SYP & WCP* & SY & SY* & BY & $\mathrm{HI}$ \\
\hline \multicolumn{11}{|l|}{ Sulphur levels } \\
\hline $\mathrm{S}_{1}: 20 \mathrm{~kg} \mathrm{~S} \mathrm{ha}^{-1}$ & 1642 & 35.2 & 10.5 & 2.70 & 4.4 & 10.5 & 566 & 1480 & 2046 & 27.6 \\
\hline $\mathrm{S}_{2}: 25 \mathrm{~kg} \mathrm{~S} \mathrm{ha}^{-1}$ & 1814 & 38.6 & 12.1 & 2.71 & 4.9 & 12.1 & 637 & 1619 & 2256 & 28.2 \\
\hline 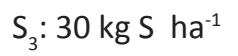 & 1989 & 40.0 & 13.3 & 2.71 & 5.4 & 13.3 & 693 & 1785 & 2451 & 28.3 \\
\hline SEm \pm & 54 & 1.20 & 0.44 & 0.004 & 0.14 & 0.44 & 19 & 56 & 75 & - \\
\hline $\mathrm{CD}(p=0.05)$ & 162 & 3.60 & 1.31 & NS & 0.44 & 1.31 & 58 & 169 & 225 & - \\
\hline \multicolumn{11}{|l|}{ Interaction $\mathrm{P} \times \mathrm{S}$} \\
\hline SEm \pm & 93 & 93 & 0.76 & 0.007 & 0.25 & 0.76 & 34 & 98 & 130 & - \\
\hline$C D(p=0.05)$ & NS & NS & NS & NS & NS & NS & 101 & NS & NS & - \\
\hline
\end{tabular}

NSP: No. of seeds plants ${ }^{-1}$; NSC: No. of seeds capsule ${ }^{-1}$; WCP: Weight of capsulesplant ${ }^{-1}(\mathrm{~g})$; TW: Test Weight (g); SYP: Seed yield plant ${ }^{-1}(\mathrm{~g})$; WCP*: Weight of capsules plant ${ }^{-1}(\mathrm{~g})$; SY: Seed yield $\left(\mathrm{kg} \mathrm{ha}^{-1}\right)$; SY*: Straw yield $\left(\mathrm{kg} \mathrm{ha}^{-1}\right)$; BY: Biological yield $\left(\mathrm{kg} \mathrm{ha}^{-1}\right) ; \mathrm{HI}$ : Harvest index (\%)

plant $^{-1}$ (2099), no. of seeds capsules ${ }^{-1}$ (43.2), seed yield pant ${ }^{-1}$ (5.7), weight of capsules plant ${ }^{-1}(13.6)$ seed yield $\left(728 \mathrm{~kg} \mathrm{ha}^{-1}\right)$, straw yield $\left(1775 \mathrm{~kg} \mathrm{ha}^{-1}\right)$ and biological yield $\left(2514 \mathrm{~kg} \mathrm{ha}^{-1}\right)$ was recorded due to the application of $30 \mathrm{~kg}$ phosphorus ha ${ }^{-1}$ and which was found significantly superior over the application of 25 and $20 \mathrm{~kg}$ phosphorus ha-1.

\subsection{Effect of sulphur on yield attributing characters}

The datapertaining to yield attributing characters is presented in Table 2 indicate that higher no. of seeds (1989), seed yield $(5.4 \mathrm{~g})$, seed yield $\left(693 \mathrm{~kg} \mathrm{ha}^{-1}\right)$ and straw yield $\left(1785 \mathrm{~kg} \mathrm{ha}^{-1}\right)$ were recorded due to the application of $30 \mathrm{~kg}$ sulphur ha-1 and which was significantly superior over the application of 20 and $25 \mathrm{~kg}$ sulphur ha-1. The higher no. of seeds capsule ${ }^{-1}$ (40.0), weight of capsules plant ${ }^{-1}$ (13.3) and biological yield $\left(2950 \mathrm{~kg} \mathrm{ha}^{-1}\right)$, were recorded due to the application of $30 \mathrm{~kg}$ sulphur ha-1, which was satisfactory at par with the application of $25 \mathrm{~kg}$ sulphur ha-1 and significantly superior over the $20 \mathrm{~kg}$ sulphur ha-1.

\section{Conclusion}

Application of $30 \mathrm{~kg}$ Phosphorus as well as $30 \mathrm{~kg}$ sulphur is essential for obtaining better yield of sesame.

\section{References}

Anonymous, 2016. Report on Oilseeds Division, Department of Agriculture,Cooperation and Farmers Welfare, Ministry of Agriculture and Farmers Welfare, Government of India.

Barik, A.K., Fulmali, J., 2011. Effect of integrated plant nutrient supply through organic and mineral sources on productivity of summer sesame. Journal of Oilseeds Research 28(2), 120-122.

Damdar, R., RBhale, V.M., Deshmukh, K.M., 2015. Growth, yield and quality of summer sesame as influencedby irrigation and Nitrogen levels. International Journal of Agricultural Science 11(2), 301-306.
Deshmukh, S.S, Sheikh, A.A, Desai, M.M., Kamble, R.S., 2010. Effect of integrated nutrient on yield of summer sesamum. Journal of Maharashtra Agricultural Universities 35(3), 453-455.

Ghodake, D.M., Alse, U.N., Suryavanshi, S.B., 2014, Effect on integrated nitrogen management on growth and yield of sesame. (Sesamum indicum L.) Journal of Oilseeds Research 31(2), 174-176.

Hafij, S.L., El-Brammawy, M.A.S., 2012. Response of sesame (Sesamum indicum L.) as affected by poultry manures, nitrogen and phosphorous at samara, Nigeria. Journal of Animal and Plant Sciences ISSN; 21(4), 1018-7080.

Haruna, I.M., Aliyu, L., Olufajo, O.O. and Odion, E.C. 2011. Growth of sesame (Sesamum indicum L.) as influenced by poultry manure, Nitrogen and Phosphorous in Samara, Nigeria. Journal of Agriculture and Environmental Sciences 10(4), 561-568.

Kushawa, D.S., 2010.Comparison of effect of biofertilizers on seedling growth and available nutrient of soil of sesame (Sesamum indicum L.) varieties. Journal of Environmental Research and Development.

Kushawa, D.S., Zia-ul-Hasan., 2010. Evaluation of growth, yield and available nutrient of soil under biofertilizers treatment in cultivar TKG-22 and TC-25 of sesame (Sesamum indicum L.). Journal of Ecology, Environment and conservation.

Mandoh, M.E., M.N., 1996. Response of sesame genotype (Sesamum indicum L.) to inoculation by different biofertilizers assiut. The Journal of Agricultural Science 27(1), 169-178.

Nayake, S.S., Koushik, B., Choudhary, R., 2014. Integrate approach in nutrient management sesamum with special reference to its yield, quality and nutrient uptake. International Journal of Life Sciences 9(1), 101-105.

Sawant, V.B., Sonami, V.V., Raskar, S.S., Patil, P.A., 2013. Effect of different level of nitrogen, phosphorous and sulphur on yield and yield attributes of summer sesame 
(Sesamum indicum L.) International Journal of Current Research 5(10), 2744-2745.

Shaikh, A.A., Desai, R.S., Kamble and Tambe, A.D., 2010. Yield of summer sesame (Sesamum indicum L.) as influenced by integrated nutrient management. International Journal of Agricultural Science, January to June 6(1), 144-146.
Shehu, H.K., Kawari, J.D., Sandabe, M.K., 2010. Effect of N P and $\mathrm{K}$ fertilizers on yield content and uptake of $\mathrm{N}, \mathrm{P}$ and $\mathrm{K}$ on sesame (Sesamum indicum L.). International Journal of Agriculture and Biology 12(6), 845-850. Varieties. Journal of Environmental research and development. 